\title{
Transformasi Lanskap dan Layanan Ekosistem Budaya di Area Peri-Urban: Wisata Alam dan Permukiman di Bandung Selatan
}

\author{
Transformation of Landscape and Cultural Ecosystem Services in Peri-Urban: \\ Nature-based Tourism and Settlement Areas in South Bandung
}

\author{
Medria Shekar Rani \\ Sekolah Arsitektur, Perencanaan, dan Pengembangan Kebijakan \\ Institut Teknologi Bandung, Bandung, Indonesia
}

Artikel Masuk : 6 Juli 2020

Artikel Diterima : 23 Maret 2021

Tersedia Online : 30 April 2021

\begin{abstract}
Abstrak: Area peri-urban menyediakan layanan ekosistem saat semakin berkurangnya luas lahan terbuka hijau di dalam kota karena densifikasi lahan terbangun. Namun, perubahan tutupan lahan dari lanskap alami menjadi perkebunan dan perumahan berpengaruh terhadap kapasitas ekosistem untuk menyediakan layanan. Penelitian ini bertujuan untuk mengidentifikasi transformasi lanskap dengan menggunakan model dan menganalisis pengaruhnya pada layanan ekosistem budaya pada area wisata alam Kawah Putih di periurban Bandung Selatan, Indonesia. Selain itu, kajian ini menganalisis bagaimana perubahan kondisi layanan ekosistem budaya dan bertambahnya kebutuhan permukiman baru di sekitar area wisata alam berpengaruh terhadap kunjungan wisatawan. Perubahan lanskap di area (1989-2019) diidentifikasi dari peta yang telah dibuat dari gambar satelit Landsat menggunakan modul Land Change Modeler (LCM) dari Terrset. Selanjutnya, kajian spasial terhadap layanan ekosistem budaya dilakukan dengan menggunakan tiga indikator berdasarkan perubahan tutupan lahan di dekat Kawah Putih. Studi ini menemukan bahwa komposisi area terbangun di kecamatan tersebut meningkat dari $6.09 \%$ menjadi $10.79 \%$ dalam 30 tahun. Kualitas dari layanan budaya telah menurun, yang disebabkan oleh adanya perubahan lanskap di kawasan studi. Meskipun demikian, jumlah wisatawan memiliki kecenderungan naik (2016-2019) walaupun terdapat penurunan kualitas lanskap. Hasil ini dipengaruhi oleh persepsi pengunjung terhadap visual lanskap di area studi. Perubahan lanskap yang cepat pada area tersebut dipengaruhi oleh pertumbuhan kota terdekat dan industri pariwisata merupakan bagian dari elemen transformasi tersebut.
\end{abstract}

Kata Kunci: layanan ekosistem budaya; pariwisata; peri-urban; transformasi lanskap

Abstract: Peri-urban provides complementary urban ecosystem services when green areas in cities are decreasing due to densification. However, land cover change in the area from natural landscapes to agriculture and settlements affects the ecosystem's capacity to provide services. This study aims to identify landscape transformation using a model and analyze its

Korespondensi Penulis: Sekolah Arsitektur, Perencanaan, dan Pengembangan Kebijakan

Email: medriasr@ar.itb.ac.id 
effects on cultural ecosystem services at Kawah Putih (White Crater) nature-based tourism destination area in the peri-urban in South Bandung, Indonesia. This study also analyzes how cultural ecosystem services and the increasing demand for new settlements in the area have influenced tourist visitation. Landscape change in the area (1989-2019) was identified from maps developed from Landsat imagery, using the Land Change Modeler (LCM) module in Terrset. A spatial assessment of offered cultural ecosystem services was then conducted using three indicators based on the land cover change near Kawah Putih. It is found that the composition of developed areas in the district has increased from $6.09 \%$ to $10.79 \%$ in 30 years. The quality of cultural ecosystem service has decreased, which is arguably influenced by the landscape alteration in the area. However, there was an increasing trend in the number of tourists (2016-2019) despite the deterioration of landscape quality. It is argued that the result is influenced by the visitors' perception of the landscape in the case study area. The rapid land cover change in the area was affected by the nearby city's growth, in which the tourism industry is one of the elements of such transformation.

Keywords: cultural ecosystem services; landscape transformation; peri-urban; tourism

\section{Pendahuluan}

Area peri-urban terletak pada zona transisi antara wilayah perdesaan dan perkotaan yang menyediakan layanan ekosistem saat berkurangnya luas lahan terbuka hijau di dalam kota karena densifikasi permukiman (Hedblom et al., 2017). Namun, dengan semakin pesatnya pertumbuhan kota, area peri-urban mengalami transformasi lanskap yang lebih cepat dibandingkan dengan area lain, seperti perkebunan atau hutan (de la Barrera et al., 2018), sehingga berdampak pada degradasi kualitas lingkungan, termasuk layanan ekosistem (Douglas, 2012). Layanan ekosistem (ecosystem services) dapat diartikan sebagai manfaat yang diberikan ekosistem bagi kesejahteraan manusia (MEA, 2005). Empat kategori dari layanan ekosistem dalam Millennium Ecosystem Assessment/MEA (2005) yaitu provisioning services, regulating services, cultural services, dan supporting services. Provisioning services merupakan layanan ekosistem yang dapat diekstraksi langsung dari alam, seperti bahan makanan, air, dan kayu. Regulating services berkaitan dengan proses ekosistem, yang mencakup di antaranya kontrol terhadap banjir dan erosi tanah. Cultural services adalah manfaat nonmaterial dari ekosistem yang didapatkan melalui pengalaman spiritual, refleksi, dan rekreasi. Supporting services berpengaruh terhadap ketiga layanan ekosistem lain dan tidak dapat langsung digunakan oleh manusia.

Klasifikasi layanan ekosistem lain di antaranya Common International Classification of Ecosystem (CICES), dengan pembagian layanan yaitu provisioning, regulation and maintenance, dan cultural (Haines-Young \& Potschin, 2018), serta klasifikasi dari The Economics of Ecosystems and Biodiversity (TEEB) yaitu provisioning services, regulating services, habitat services, dan cultural and amenity services. Perbandingan klasifikasi dari TEEB dengan sistem lain serta daftar indikator penilaian kondisi layanan ekosistem tercantum dalam dokumen TEEB (2010).

Salah satu bentuk cultural services yang diberikan area peri-urban yaitu berupa komponen biotik untuk menunjang aktivitas rekreasi dan ekowisata. Rekreasi dan wisata alam memberikan sarana pengelolaan, pelestarian alam, dan interaksi langsung antara manusia dan ekosistem, terutama bagi masyarakat perkotaan yang kontaknya dengan ekosistem alami atau semi-alami sudah terbatas (Daniel et al., 2012). Keindahan lanskap merupakan salah satu atraksi dari area wisata alam. Analisis keindahan lanskap (landscape aesthetics) dapat dilakukan baik secara objektif maupun subjektif (Le et al., 2019). Le et al. (2019) lebih lanjut menuliskan bahwa studi keindahan lanskap dalam paradigma objektivisme dapat memberikan gambaran umum preferensi manusia terhadap keindahan lanskap. Di sisi lain, perbedaan preferensi keindahan terhadap objek lanskap yang sama 
dari setiap individu dapat dikaji dalam paradigma subjektivisme. Perbedaan persepsi terhadap daya tarik objek wisata dapat memengaruhi kepuasan wisatawan dan keinginan berkunjung kembali (Mat-Som \& Bader-Badarneh, 2011).

Identifikasi hubungan timbal balik (trade-off) antara pemenuhan cultural services dengan provisioning services di area peri-urban telah dibahas sebelumnya (Spyra et al., 2020). Beberapa studi menunjukkan bahwa aktivitas wisata dapat memberikan dampak negatif terhadap ekosistem (Gerhard et al., 2005). Di sisi lain, perubahan tutupan lahan, seperti dari lanskap alami menjadi area pertanian dan permukiman dapat berpengaruh pada kapasitas ekosistem untuk memberikan layanan (Kangas et al., 2018). Di antara seluruh komponen layanan ekosistem yang ada, layanan budaya telah diakui secara luas, tetapi belum cukup terdefinisi atau diintegrasikan ke dalam kerangka layanan ekosistem (Daniel et al., 2012), termasuk manfaatnya terhadap kesejahteraan manusia (well-being) (Kosanic \& Petzold, 2020).

Penelitian-penelitian sebelumnya telah dilakukan untuk menganalisis layanan ekosistem budaya dan peri-urban. Slámová et al. (2018) menganalisis kualitas lanskap hutan dengan menggunakan pendekatan multi-criteria, dan keterjangkauannya dari pusat kota Zvolen di Slovakia. Mngumi (2019) menjabarkan bahwa industri pariwisata, termasuk di dalamnya wisata alam, merupakan bagian dari adaptasi perubahan iklim dari sistem sosio-ekologi di peri-urban Dar es Salaam, Tanzania. Menurunnya kualitas layanan ekosistem di kawasan ini diakibatkan oleh berkurangnya kawasan hutan dan meningkatnya kebutuhan area untuk permukiman dan perkebunan. Ekowisata merupakan salah satu pilihan pemanfaatan layanan ekosistem selain kegiatan perkebunan, yang dapat meningkatkan ketahanan komunitas (community resilience) terhadap perubahan iklim.

Dalam ranah studi layanan ekosistem budaya di peri-urban, kajian yang mengintegrasikan analisis menggunakan model masih terbatas. Tieskens et al. (2018) menggunakan foto-foto dari media sosial dan generalized linear modeling (GLM) untuk melihat korelasi antara atribut lanskap dengan preferensi wisatawan di Kromme Rijin, area perkebunan di peri-urban Utrecht, Belanda. Studi tersebut menemukan bahwa visual lanskap bukan merupakan satu-satunya faktor yang mendorong pengunjung datang ke kawasan wisata. Sehingga metode tambahan diperlukan untuk mengetahui motivasi pengunjung tersebut. Penelitian dari Putt et al. (2019) membahas dampak kegiatan wisata di sekitar danau Cultus, British Colombia, Kanada terhadap terjadinya eutrofikasi dan degradasi kualitas air, yang kemudian dapat menurunkan nilai dari cultural services danau tersebut. Penelitian ini menggunakan model untuk mengukur kualitas air dan membangun proyeksi kondisi di masa depan berdasarkan skenario. Namun, hubungan antara kondisi lingkungan dengan kunjungan wisatawan tidak dibahas dalam riset ini. Oleh karena itu, penelitian pada studi ini berfokus pada kajian layanan ekosistem budaya pada area wisata alam di peri-urban menggunakan model lanskap dan melihat keterkaitannya dengan kunjungan wisatawan.

Penelitian ini bertujuan untuk mengidentifikasi transformasi lanskap dengan menggunakan model dan menganalisis pengaruhnya pada layanan ekosistem budaya pada area wisata alam Kawah Putih di area peri-urban Bandung Selatan. Dalam studi ini, model digunakan sebagai alat untuk memahami faktor-faktor yang memengaruhi bentuk lanskap, yaitu dengan melakukan simulasi terhadap perubahan lanskap pada periode waktu tertentu (Urban \& Wallin, 2017). Selain itu, kajian ini menganalisis bagaimana perubahan kondisi layanan ekosistem budaya dan bertambahnya kebutuhan permukiman baru di sekitar area wisata alam berpengaruh terhadap kunjungan wisatawan. Kawah Putih di dalam area studi dikembangkan sebagai area wisata alam pada tahun 1987 dan dikelola oleh Kesatuan Bisnis Mandiri (KBM) Ecotourism Jawa Barat dan Banten dari Perhutani, dengan kolaborasi bersama warga sekitar. Terdapat peningkatan jumlah total kunjungan wisatawan sebanyak 
66 Transformasi Lanskap dan Layanan Ekosistem Budaya di Area Peri-Urban ...

283.934 wisatawan di tahun 2016, 374.931 wisatawan di tahun 2017, dan 497.189 wisatawan di tahun 2018 (PT Perhutani Unit III Jawa Barat, 2019).

\section{Metode Penelitian}

Diagram alur kerja penelitian dapat dilihat pada Gambar 1. Penelitian ini dilakukan dalam tiga tahap pekerjaan, meliputi: (1) pemetaan tutupan lahan Kecamatan Rancabali dan kawasan Kawah putih secara khusus, (2) identifikasi perubahan tutupan untuk melihat transformasi lanskap peri-urban Kecamatan Rancabali (1989-2019), dan (3) indentifikasi kondisi layanan ekosistem budaya di area wisata alam Kawah Putih dan sekitarnya berdasarkan transformasi lanskap yang terjadi dalam kurun waktu 30 tahun.

Data spasial terdiri dari gambar satelit Landsat dan Digital Elevation Model (DEM). Gambar Landsat diunduh dari laman EROS (Earth Resources Observation and Science) yang dikelola oleh USGS (United States Geological Survey) (https://earthexplorer.usgs.gov/). Sedangkan gambar DEM bersumber dari DEMNAS dan diperoleh dari Badan Informasi Geospasial (BIG) (http://tides.big.go.id/DEMNAS/). Selain itu, data nonspasial yang digunakan dalam penelitian ini adalah data kunjungan wisatawan ke area Kawah Putih tahun 2016-2020 dari PT Perhutani Unit III Jawa Barat. Foto-foto kawasan diakses dari Google Street sebagai data urun daya (crowdsourcing) yang digunakan karena tidak dapat dilakukannya pengamatan langsung saat pandemi.

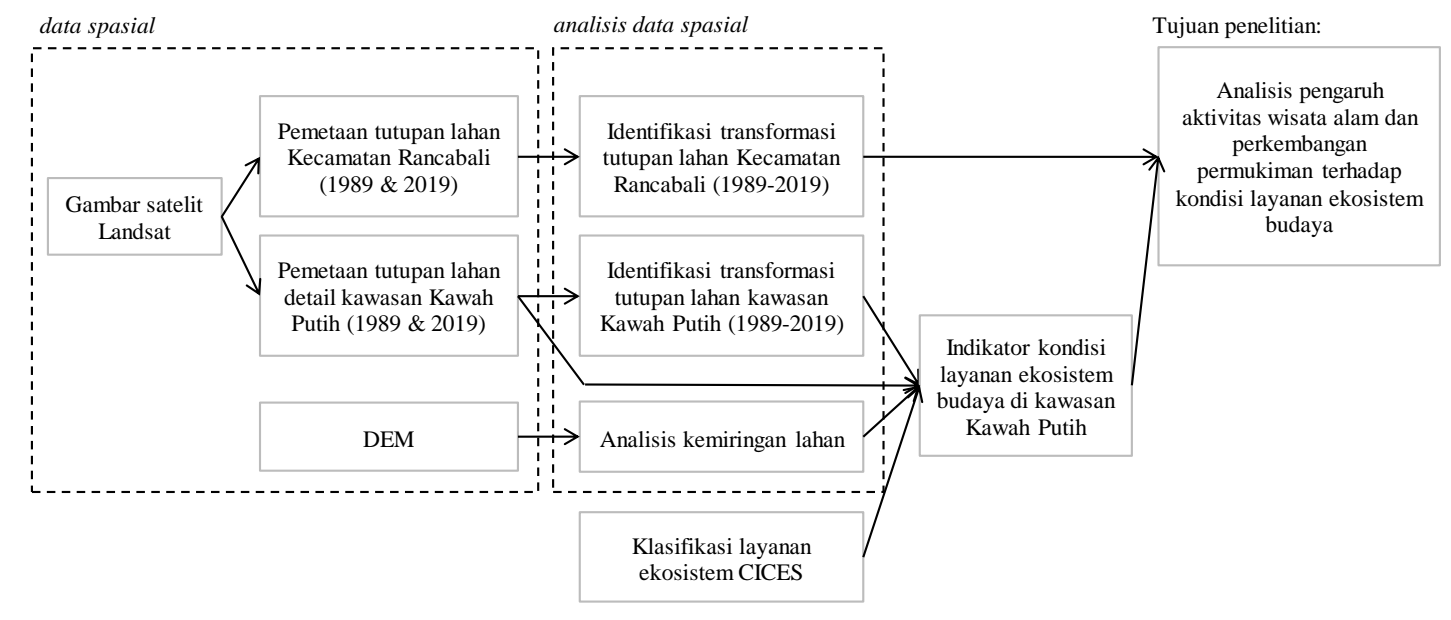

Gambar 1. Diagram Alur Kerja Penelitian

\section{Pemetaan Tutupan Lahan}

Gambar satelit Landsat Kecamatan Rancabali $\left(148,37 \mathrm{~km}^{2}\right)$, yang diambil pada tanggal 6 Juli 1989 dan 25 Juli 2019 (Gambar 2), digunakan dalam proses pembuatan peta tutupan lahan dengan metode unsupervised classification dengan ArcGIS. Proses klasifikasi pada metode ini tidak membutuhkan pengetahuan terhadap area studi sebelumnya dan dapat dilakukan secara otomatis dengan perangkat lunak (Champbell \& Wynne, 2011). Piksel dengan nilai reflektansi objek badan air, awan, dan bayangan awan pada gambar satelit sebelumnya telah dipetakan dan dipisahkan dari bagian gambar lainnya (water, cloud and cloud shadow masking) dengan menggunakan fungsi Fmask pada plugin CloudMasking di QGIS (https://plugins.qgis.org/plugins/CloudMasking/). 
Tutupan lahan (land cover) untuk peta Kecamatan Rancabali diklasifikasikan menjadi tiga kelas besar, yaitu area terbangun, area tidak terbangun, dan badan air. Area terbangun mencakup area permukiman dan area perkerasan lainnya. Contoh area tidak terbangun di antaranya yaitu tanah kosong, perkebunan, dan hutan. Sedangkan badan air pada kawasan yaitu danau dan kawah.

Peta tutupan (1989 dan 2019) yang lebih rinci juga dibuat untuk kawasan wisata Kawah Putih dan area di sekitarnya (elevasi lebih dari $1.775 \mathrm{mdpl}$ ) untuk proses analisis kondisi layanan ekosistem budaya. Dengan cakupan wilayah analisis yang lebih kecil dari kecamatan $\left(14,15 \mathrm{~km}^{2}\right)$, maka kelas tutupan lahan area tidak terbangun dapat dipecah menjadi dua subkelas, yaitu subkelas hutan, dan subkelas perkebunan dan tanah kosong. Sehingga terdapat total empat kelas tutupan lahan untuk area ini.

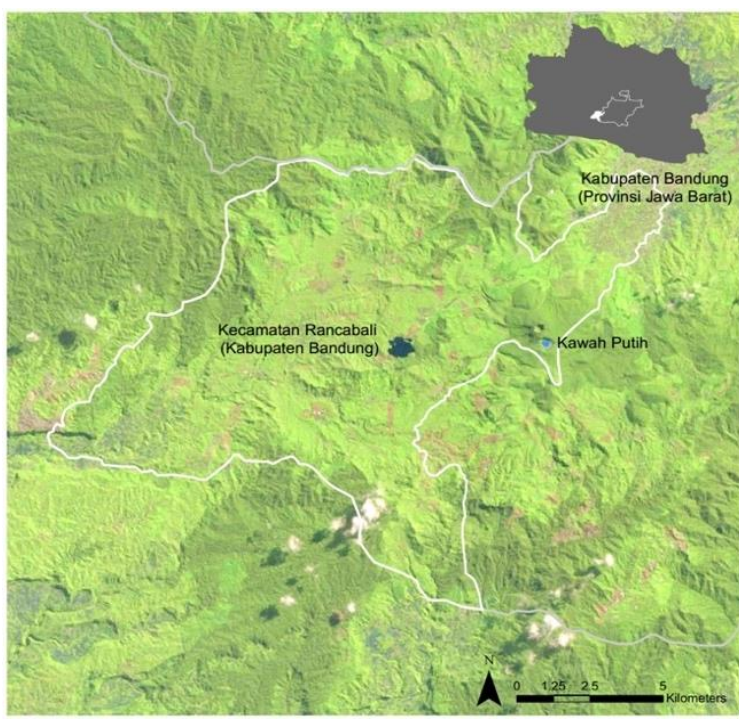

(a)

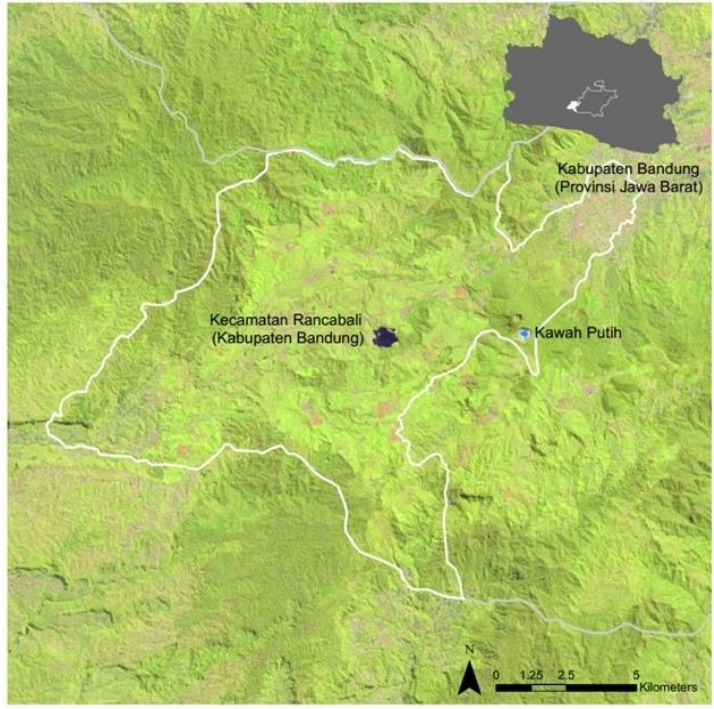

(b)

Sumber: diolah dari gambar Landsat United States Geological Survey tahun 1989 dan 2019

Gambar 2. Gambar Satelit Kecamatan Rancabali Tahun (a) 1989 dan (b) 2019

\section{Transformasi Tutupan Lahan}

Transformasi tutupan lahan Kecamatan Rancabali diidentifikasi dari gambar satelit Landsat tahun 1989 dan 2019 dengan menggunakan modul Land Change Modeler (LCM) dari perangkat lunak Terrset. Prosedur analisis meliputi evaluasi pertambahan dan pengurangan persentase tutupan lahan yang berubah dan pemetaan lokasi lanskap yang mengalami perubahan dalam satu periode waktu (Eastman, 2006). Dalam penelitian ini, transformasi tutupan lahan pada skala lebih detail di kawasan Kawah Putih dan sekitarnya juga dipetakan untuk selanjutnya digunakan dalam proses idenfikasi layanan ekosistem budaya di tahun 1989 dan 2019.

\section{Identifikasi Kondisi Layanan Ekosistem Budaya}

Tabel 1 memperlihatkan kelas CICES terkait dengan idenfikasi layanan ekosistem budaya di kawasan wisata Kawah Putih. Kaitan komponen biotik dan abiotik dalam kelas CICES dengan kelas layanan ekosistem dari MEA, (2005) dan TEEB (2010) kemudian dijabarkan. Indikator untuk mengidentifikasi kondisi layanan ekosistem pada tahun 1989 dan 2019 (Tabel 2) ditetapkan dengan merujuk pada Tabel 1 dan ketersediaan data spasial. 
Penyusunan indikator juga merujuk pada studi literatur tentang kajian layanan ekosistem budaya, seperti Thiele et al. (2020). Pemetaan dilakukan dengan menggunakan ArcGIS dalam rentang nilai 0-1 untuk tiap piksel berukuran $30 \mathrm{~m}$, mengikuti resolusi gambar satelit Landsat.

\section{Tabel 1. Kelas CICES Terkait Penetapan Indikator Penilaian Kondisi Layanan Ekosistem Budaya di Wilayah Studi}

\begin{tabular}{|c|c|c|c|}
\hline Kelas CICES & $\begin{array}{c}\text { Ekuivalensi } \\
\text { dengan kelas MA }\end{array}$ & $\begin{array}{c}\text { Ekuivalensi dengan } \\
\text { Kelas TEEB }\end{array}$ & $\begin{array}{c}\text { Aplikasi Penilaian } \\
\text { Kondisi Layanan } \\
\text { Ekosistem Budaya }\end{array}$ \\
\hline $\begin{array}{l}\text { Karakteristik komponen biotik } \\
\text { untuk menunjang aktivitas yang } \\
\text { bermanfaat bagi kesehatan dan } \\
\text { memberikan kesenangan melalui } \\
\text { interaksi aktif dan pasif (kode } \\
\text { 3.1.1.1 dan 3.1.1.2) }\end{array}$ & $\begin{array}{l}\text { Rekreasi dan } \\
\text { ekowisata }\end{array}$ & $\begin{array}{l}\text { Rekreasi dan } \\
\text { ekowisata. }\end{array}$ & $\begin{array}{l}\text { Kondisi } \\
\text { biodiversitas: } \\
\text { penilaian ekosistem } \\
\text { dan spesies tertentu }\end{array}$ \\
\hline $\begin{array}{l}\text { Karakteristik komponen biotik } \\
\text { untuk menunjang pendidikan dan } \\
\text { pelatihan (kode } 3.1 .2 .2 \text { ) }\end{array}$ & $\begin{array}{l}\text { Sistem pendidikan, } \\
\text { nilai edukasi, } \\
\text { keberagaman } \\
\text { budaya, dan nilai } \\
\text { estetis }\end{array}$ & $\begin{array}{l}\text { Informasi dan } \\
\text { perkembangan } \\
\text { kognitif }\end{array}$ & $\begin{array}{l}\text { Kondisi ekosistem: } \\
\text { penilaian tingkat } \\
\text { layanan ekosistem } \\
\text { dan perubahan }\end{array}$ \\
\hline $\begin{array}{l}\text { Karakteristik komponen biotik } \\
\text { untuk menunjang pengalaman } \\
\text { estetis (kode } 3.1 .2 .4 \text { ) }\end{array}$ & $\begin{array}{l}\text { Sistem pendidikan, } \\
\text { nilai edukasi, } \\
\text { keberagaman } \\
\text { budaya, dan nilai } \\
\text { estetis }\end{array}$ & $\begin{array}{l}\text { Inspirasi untuk } \\
\text { aktivitas terkait } \\
\text { budaya, seni dan } \\
\text { desain, informasi } \\
\text { estetis }\end{array}$ & \\
\hline $\begin{array}{l}\text { Karakteristik alami komponen } \\
\text { abiotik untuk kegiatan aktif dan } \\
\text { pasif serta interaksi yang } \\
\text { menunjang pengalaman dan } \\
\text { intelektual (kode 6.1.1.1 dan } \\
\text { 6.1.2.1) }\end{array}$ & $\mathrm{t} / \mathrm{a}$ & $\mathrm{t} / \mathrm{a}$ & $\mathrm{t} / \mathrm{a}$ \\
\hline
\end{tabular}

Sumber: MEA, 2005; TEEB, 2010

\section{Tabel 2. Indikator, Jenis dan Sumber Data untuk Proses Identifikasi Kondisi Layanan Ekosistem Budaya}

\begin{tabular}{|c|c|c|c|}
\hline Kode kelas CICES & Indikator & Jenis data & Sumber data \\
\hline \multirow[t]{2}{*}{$\begin{array}{l}\text { Kode } 3.1 .1 .1 ; 3.1 .1 .2 ; \\
3.1 .2 .2 ; 3.1 .2 .4\end{array}$} & $\begin{array}{l}\text { Tutupan lahan di sekitar } \\
\text { Kawah Putih }\end{array}$ & $\begin{array}{l}\text { Peta tutupan lahan tahun } \\
1989 \text { dan } 2019\end{array}$ & $\begin{array}{l}\text { Unsupervised } \\
\text { classification dari } \\
\text { gambar satelit Landsat } \\
\text { (USGS) }\end{array}$ \\
\hline & & $\begin{array}{l}\text { Peta perubahan tutupan } \\
\text { lahan (1989-2019) }\end{array}$ & Hasil analisis \\
\hline Kode $6.1 .1 .1 ; 6.1 .2 .1$ & Keberadaan kawah & Gambar satelit & Landsat (USGS) \\
\hline Kode $6.1 .1 .1 ; 6.1 .2 .1$ & $\begin{array}{l}\text { Pengalaman ruang } \\
\text { terkait bentukan lahan }\end{array}$ & $\begin{array}{l}\text { Digital Elevation Model } \\
\text { (DEM) }\end{array}$ & $\begin{array}{l}\text { DEMNAS dari Badan } \\
\text { Informasi Geospasial } \\
\text { (BIG) }\end{array}$ \\
\hline
\end{tabular}

Sumber: Haines-Young \& Potschin, 2018 
Indikator pertama yaitu tutupan lahan di sekitar Kawah Putih terkait dengan fungsi kawasan untuk mengakomodasi kegiatan yang bermanfaat bagi kesehatan dan memberikan kesenangan melalui interaksi alam secara aktif dan pasif. Pemetaan kondisi layanan dengan indikator pertama dilakukan dengan menggunakan peta tutupan lahan tahun 1989 dan 2019. Hutan di tahun 1989 diasumsikan adalah hutan alami. Sedangkan lokasi hutan alami di tahun 2019 diidentifikasi dari analisis perubahan tutupan lahan (1989-2019). Piksel dengan tutupan hutan alami memiliki nilai tertinggi yaitu 1, dan piksel dengan tutupan lahan terbangun (seperti perumahan) memiliki nilai terendah yaitu 0. Nilai 0,3 untuk piksel dengan tutupan lahan, lahan kosong dan perkebunan, dan nilai 0,7 untuk hutan baru di tahun 2019, ditentukan berdasarkan studi literatur dari Thiele et al. (2020) dengan penyesuaian.

Indikator kedua yaitu keberadaan kawah di kawasan studi. Nilai 1 diberikan pada piksel dengan tutupan lahan berupa kawah, dan nilai 0 untuk piksel jenis lainnya. Indikator ketiga yaitu pengalaman ruang terkait bentukan lahan yang disusun dari data Digital Elevation Model(DEM). Rentang nilai 0 hingga 1 ditetapkan berdasarkan tingkat kerapatan garis kontur atau kemiringan lahan. Akumulasi nilai dari tiga indikator dihitung untuk setiap piksel pada kondisi di tahun 1989 dan 2019. Nilai tertinggi menandakan area dengan kualitas layanan ekosistem budaya yang paling baik di kawasan studi.

Di dalam studi ini, analisis regresi linear digunakan untuk melihat kecenderungan tingkat kunjungan wisatawan di dalam kawasan Kawah Putih. Kajian transformasi tutupan lahan di Kecamatan Rancabali secara keseluruhan, bersama dengan perbandingan hasil pemetaan indikator tahun 1989 dan 2019 dan hasil analisis regresi linear kemudian dianalisis lebih lanjut untuk melihat efek perubahan lanskap dan aktivitas wisata terhadap kondisi layanan ekosistem budaya (rekreasi) di area studi.

\section{Hasil dan Pembahasan}

\section{Pemetaan Tutupan Lahan}

Klasifikasi tutupan lahan Kecamatan Rancabali tahun 1989 dan 2019 dilakukan terhadap piksel selain yang telah diidentifikasi sebagai badan air, awan dan bayangan awan melalui proses masking. Oleh karena itu, peta tutupan lahan yang dihasilkan tidak meliputi keseluruhan area dari Kecamatan Rancabali (Gambar 3). Keterbatasan data satelit tanpa tutupan awan menjadi kendala pada pengerjaan klasifikasi tutupan lahan di wilayah tropis (Toure et al., 2018). Area kawah secara otomatis diidentifikasi ke dalam kelas area terbangun karena kesamaan rentang reflektansi piksel. Namun, area ini diklasifikasikan kembali sebagai kawah atau badan air pada proses analisis selanjutnya.

Dalam penelitian ini, pemetaan tutupan lahan Kecamatan Rancabali terbatas pada tiga kelas besar (area terbangun, area tidak terbangun, dan badan air) sebagai data untuk proses analisis perubahan tutupan lahan dengan LCM. Sedangkan klasifikasi tutupan lahan yang lebih detail dibutuhkan untuk proses analisis kondisi layanan ekosistem budaya di kawasan Kawah Putih, sehingga terdapat empat kelas tutupan lahan pada area ini (area terbagun, perkebunan dan area terbuka, hutan, dan badan air). Peta ini dapat dilihat pada Gambar 4 dengan tingkat akurasi peta 86.80\% untuk peta tahun 2019.

Proses klasifikasi dibantu dengan interpretasi visual gambar WorldView-2 (resolusi $0,5 \mathrm{~m}$ ), sebagai peta dasar World Imagery di ArcGIS. Pemilihan metode unsupervised classification dan interpretasi gambar dilakukan karena adanya keterbatasan akses untuk melakukan survei lapangan selama proses analisis. Perlu diperhatikan bahwa proses identifikasi tutupan lahan dilakukan langsung dari data penginderaan jauh. Tidak ada prosedur koreksi gambar satelit untuk menyesuaikan nilai reflektansi yang telah berubah 
karena kondisi atmosfer dan efek topografi lahan (atmospheric and topographic corrections).

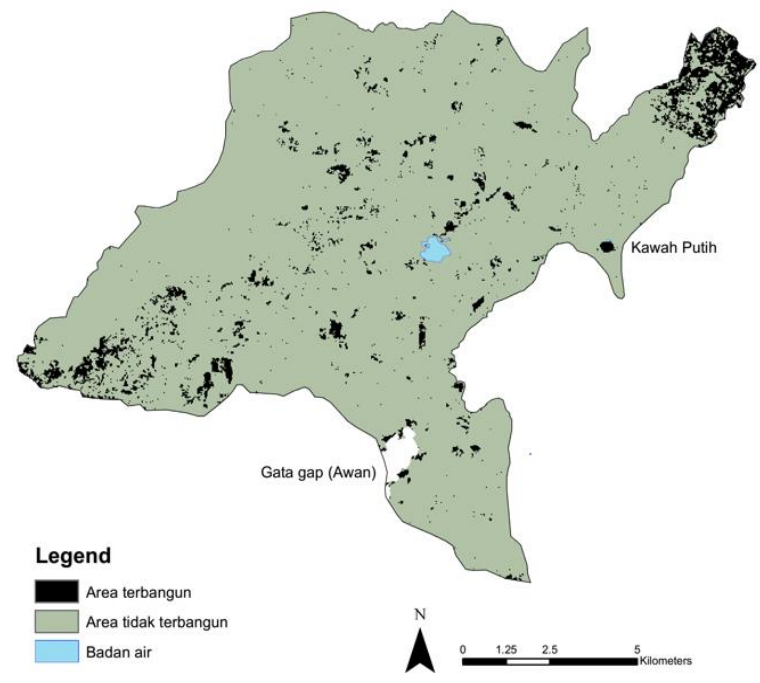

(a)

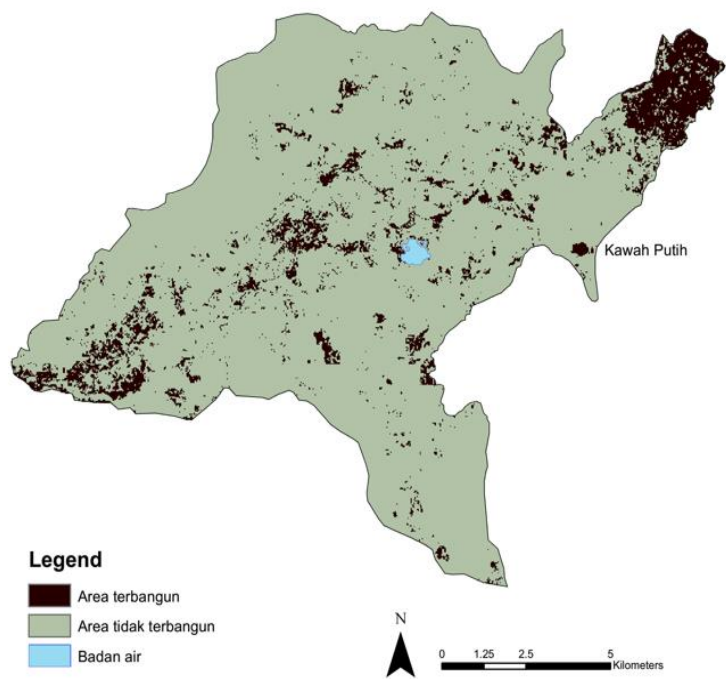

(b)

Gambar 3. Hasil Klasifikasi Peta Tutupan Lahan Kecamatan Rancabali Tahun (a) 1989 dan (b) 2019

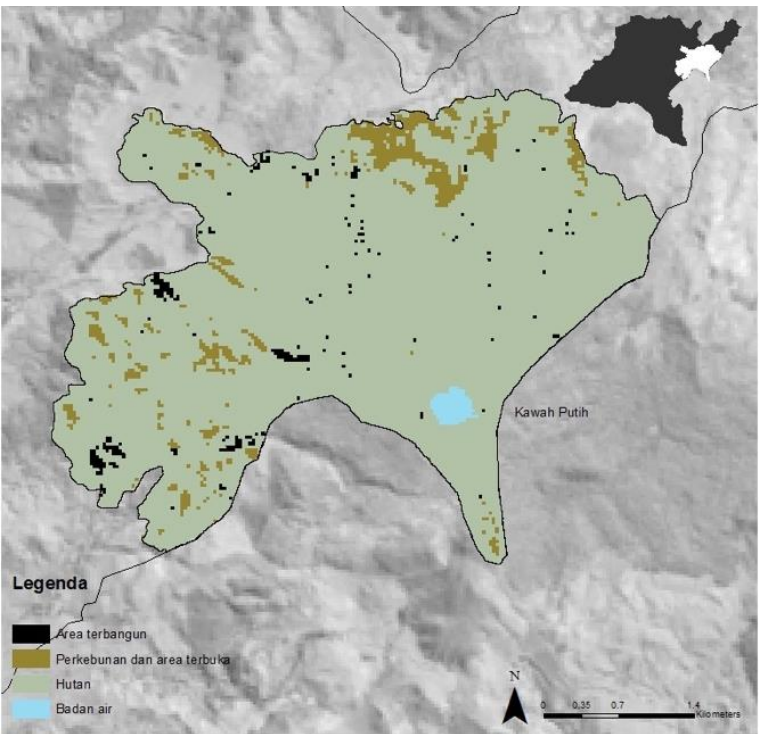

(a)

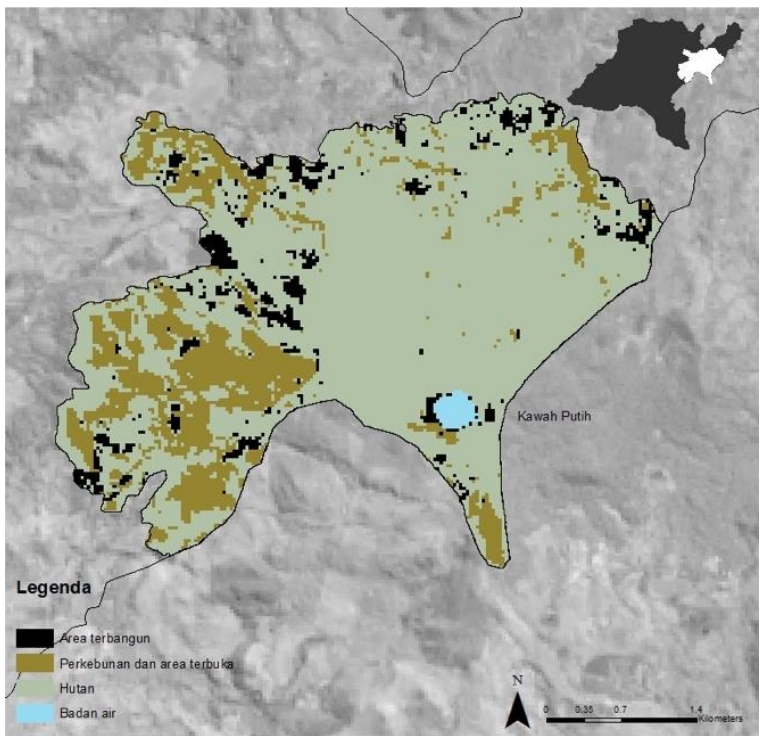

(b)

Gambar 4. Hasil Klasifikasi Peta Tutupan Lahan Detail untuk Kawasan Wisata Kawah Putih dan Sekitarnya Tahun (a) 1989 dan (b) 2019

Penggunaan gambar satelit Landsat dalam pemetaan perubahan tutupan lahan di studi kasus mendemonstrasikan bagaimana riset serupa dapat dilakukan di area lain ketika terdapat kendala keterbatasan data spasial. Gambar satelit ini dapat diunduh langsung pada laman USGS, yang datanya selalu diperbarui secara berkala, sehingga memudahkan peneliti mengakses kebutuhan gambar pada waktu yang diperlukan. Salah satu limitasi dari 
pendekatan ini adalah resolusi gambar yaitu 30 meter, sehingga terdapat kemungkinan adanya nilai piksel yang bercampur (mixed pixels). Kendala lain yaitu kurangnya informasi tutupan lahan (data gap) pada beberapa piksel karena keberadaan awan dan bayangan awan, seperti yang terlihat pada hasil pemetaan tutupan lahan di studi kasus tahun 1989 (Gambar 3). Tutupan awan pada gambar satelit merupakan permasalahan dalam proses klasifikasi tutupan lahan termasuk vegetasi, terutama di area tropis (Helmer et al., 2012; Toure et al., 2018).

\section{Transformasi Tutupan Lahan}

Keluaran dari proses masking awan dan bayangan awan dari gambar tahun 1989 digunakan untuk prosedur masking piksel di lokasi yang sama pada gambar tahun 2019, sehingga kedua gambar memiliki lokasi data gap (piksel tanpa data) yang sama dan proses identifikasi perubahan lanskap dapat dilakukan. Analisis terhadap peta tutupan lahan Kecamatan Rancabali (Gambar 3) menunjukkan peningkatan komposisi lahan terbangun dari 6,09\% di tahun 1989 menjadi 10,79\% di tahun 2019. Persentase luas tutupan lahan dilakukan terhadap peta dari gambar satelit dengan piksel tanpa data di tahun 1989, sehingga komposisi ini tidak dapat mewakili kondisi sebenarnya di lapangan. Alternatif pembuatan peta tutupan lahan dengan piksel tanpa data pada gambar satelit adalah dengan teknik updating dan backdating (Linke et al., 2009). Teknik ini membutuhkan beberapa gambar satelit yang diambil pada waktu yang berdekatan sehingga piksel tanpa data pada satu gambar dapat diisi dengan data pada gambar lainnya.

Hasil LCM memperlihatkan terdapat perubahan tutupan di Kecamatan Rancabali dalam periode 30 tahun dari tidak terbangun menjadi terbangun seluas $6,91 \mathrm{~km}^{2}$, terutama di bagian timur laut, tengah, dan barat daya lahan (Gambar 5a). Salah satu faktor yang dapat memengaruhi distribusi perubahan tutupan lahan adalah derajat kemiringan lahan (Gambar 5b). Terdapat kecenderungan untuk membangun permukiman baru pada area dengan kemiringan kurang dari $10^{\circ}$ (lingkaran merah pada Gambar 5b) dan hampir tidak ada pembangunan pada lahan miring $\left(>20^{\circ}\right)$. Faktor lain yang berpengaruh pada lokasi permukiman baru, seperti kedekatan dengan eksisting jaringan jalan, elevasi lahan, dan jumlah penduduk pada satu area, dapat dianalisis lebih lanjut. Namun, konteks pembahasan tersebut di luar ranah fokus penelitian ini.

Perkembangan pembangunan di peri-urban juga dapat dipengaruhi oleh lokasi objek wisata, seperti yang terjadi di sekitar Situ Cileunca, Kabupaten Bandung (Pratiwi et al., 2019). Dalam studi kasus di Kawah Putih, transformasi lanskap yang diamati terjadi dari tutupan hutan menjadi area terbuka dan terbangun di sekitar kawah pada tahun 2019. Area Kawah Putih masuk ke dalam kawasan hutan lindung, sehingga tidak banyak perubahan lanskap di luar batas kawah hingga pada radius sekitar 1-2 km dari kawah (Gambar 4). Studi de la Barrera et al. (2018) memperlihatkan transformasi lanskap vegetasi asli bernilai tinggi menjadi area terbangun di peri-urban Santiago Metropolitan (1989-2015) dapat berpengaruh pada aktivitas wisata dan pembentukan sense of place, sebagai bagian dari layanan budaya. Perubahan tutupan lahan yang cepat pada area peri-urban didorong oleh tingginya investasi untuk pembangunan dan kapasitas area memberikan layanan ekosistem yang dapat diakses secara mudah dari kota di dekatnya (de la Barrera et al., 2018).

\section{Identifikasi Kondisi Layanan Ekosistem Budaya}

Tahap selanjutnya dari proses analisis adalah kajian kondisi layanan ekosistem budaya kawasan wisata alam Kawah Putih dan sekitarnya. Hasil pemetaan kondisi layanan ekosistem tahun 1989 dan 2019 berdasarkan tiga indikator yang ditetapkan (tutupan lahan di sekitar Kawah Putih, keberadaan kawah, dan pengalaman ruang terkait bentukan lahan) ditampilkan dalam Gambar 6. 
Hutan alami yang terletak pada lahan yang curam $\left(>30^{\circ}\right)$ memiliki akumulasi nilai tertinggi yaitu 2. Terdapat penurunan nilai rata-rata (mean) piksel, yaitu 1,19 untuk kondisi layanan di tahun 1989 menjadi 1,04 di tahun 2019. Selain itu, jumlah piksel dengan nilai yang rendah di bawah 1 meningkat dari $1.235\left(1,11 \mathrm{~km}^{2}\right)$ menjadi $4.526\left(4,07 \mathrm{~km}^{2}\right)(\mathrm{Gambar}$ 7). Hal ini mengindikasikan adanya penurunan kualitas layanan ekosistem budaya (rekreasi) karena semakin luasnya area dengan kondisi lingkungan yang tidak dapat mendukung kegiatan wisata alam.

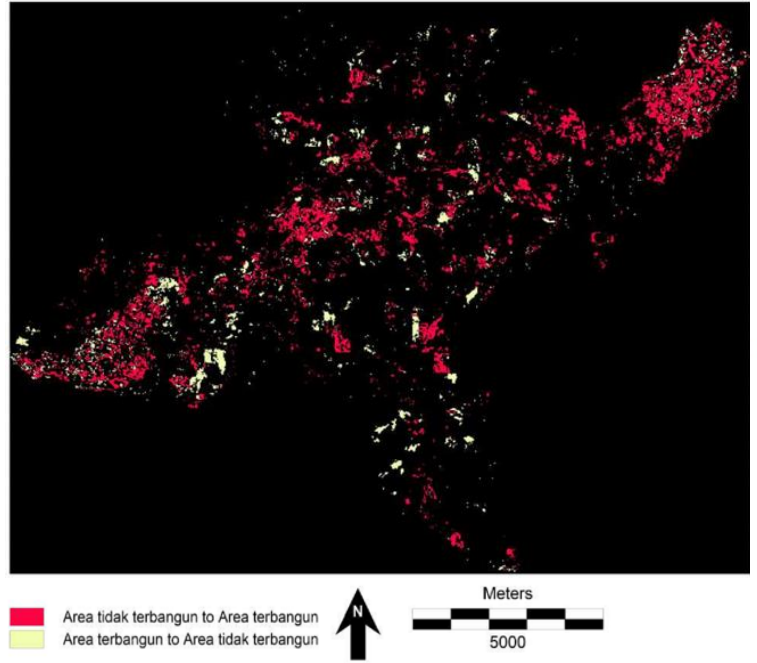

(a)

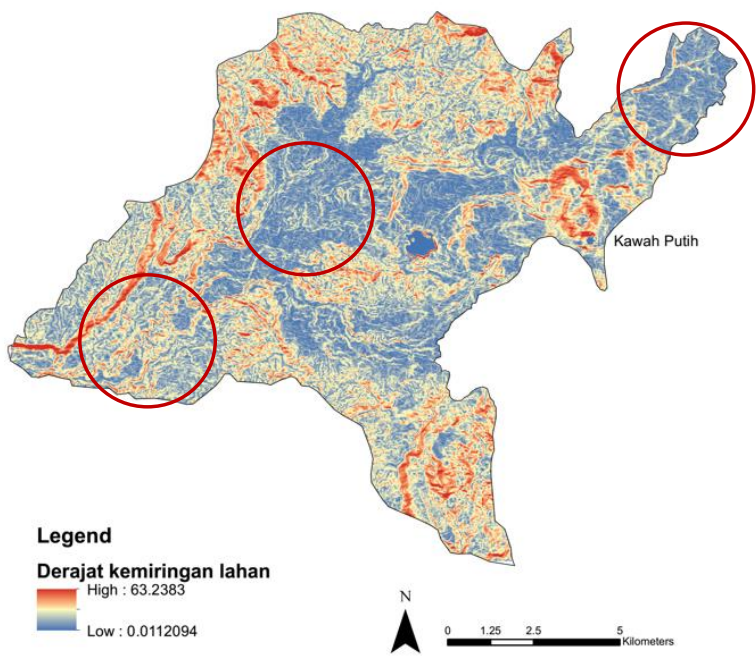

(b)

Sumber : DEM dari DEMNAS BIG 2018 dan Analisis LCM

Gambar 5. (a) Perubahan Tutupan Lahan di Kecamatan Rancabali (1989-2019) dan (b) Peta Kemiringan Lahan (dalam derajat) Kecamatan Rancabali

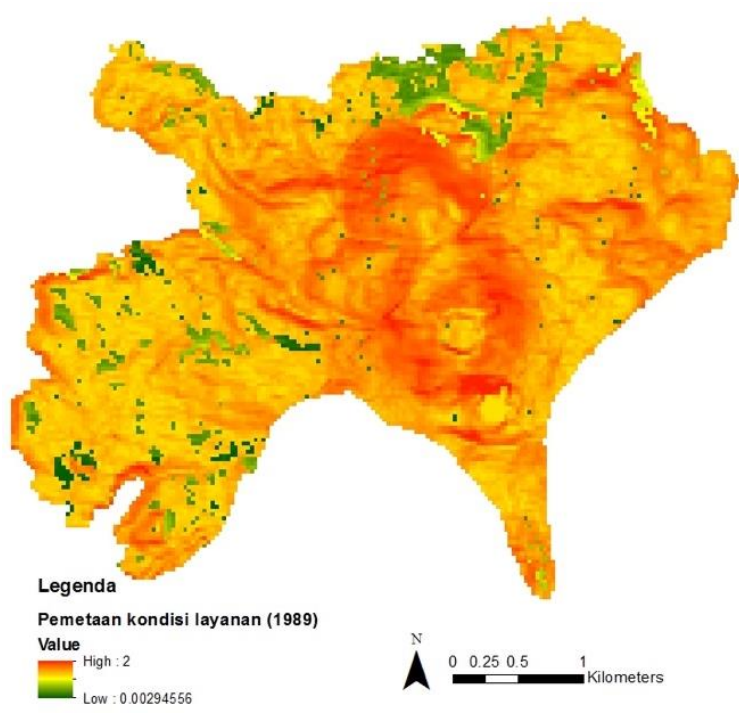

(a)

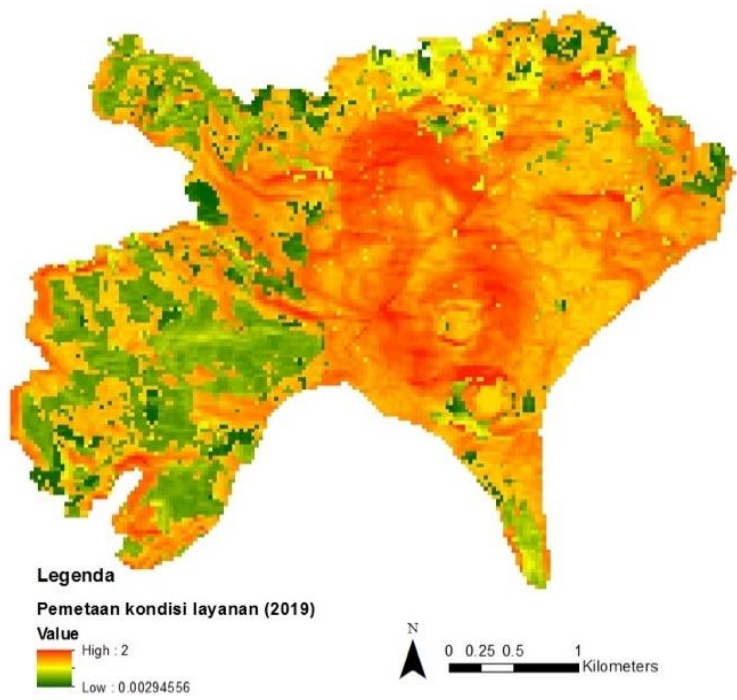

(b)

\section{Gambar 6. Hasil Pemetaan Kondisi Layanan Ekosistem Budaya (Rekreasi)} Tahun (a) 1989 dan (b) 2019 
Analisis lebih lanjut dari dua peta tata guna lahan (1989 dan 2019) menunjukkan tutupan hutan telah mengalami penurunan dari $91,35 \%$ menjadi $72,89 \%$ dalam 30 tahun. Hutan di bagian barat dan selatan kawasan mengalami perubahan menjadi area perkebunan. Selain itu, terdapat pertambahan area terbuka (batu kapur) di bagian barat dan selatan Kawah Putih (Gambar 8). Hal ini menunjukkan adanya transformasi lanskap yang dapat langsung dilihat oleh wisatawan saat berkunjung ke area Kawah Putih.

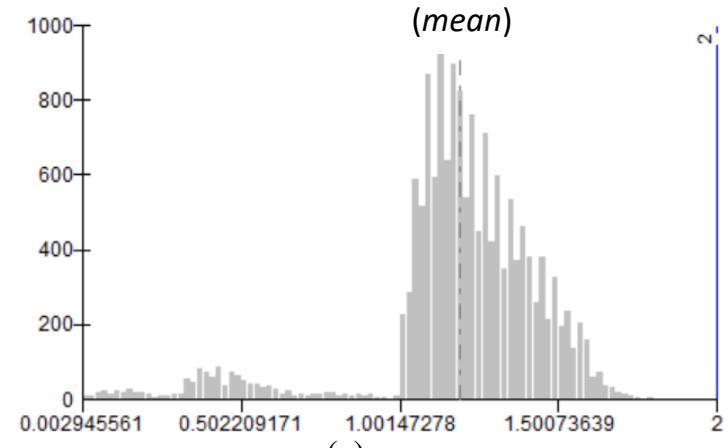

(a)

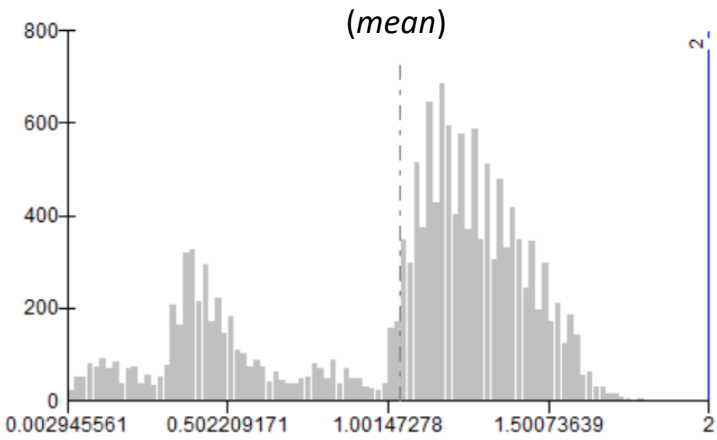

(b)

\section{Gambar 7. Distribusi Nilai Piksel untuk Pemetaan Kondisi Layanan Ekosistem Budaya (Rekreasi) Tahun (a) 1989 dan (b) 2019}

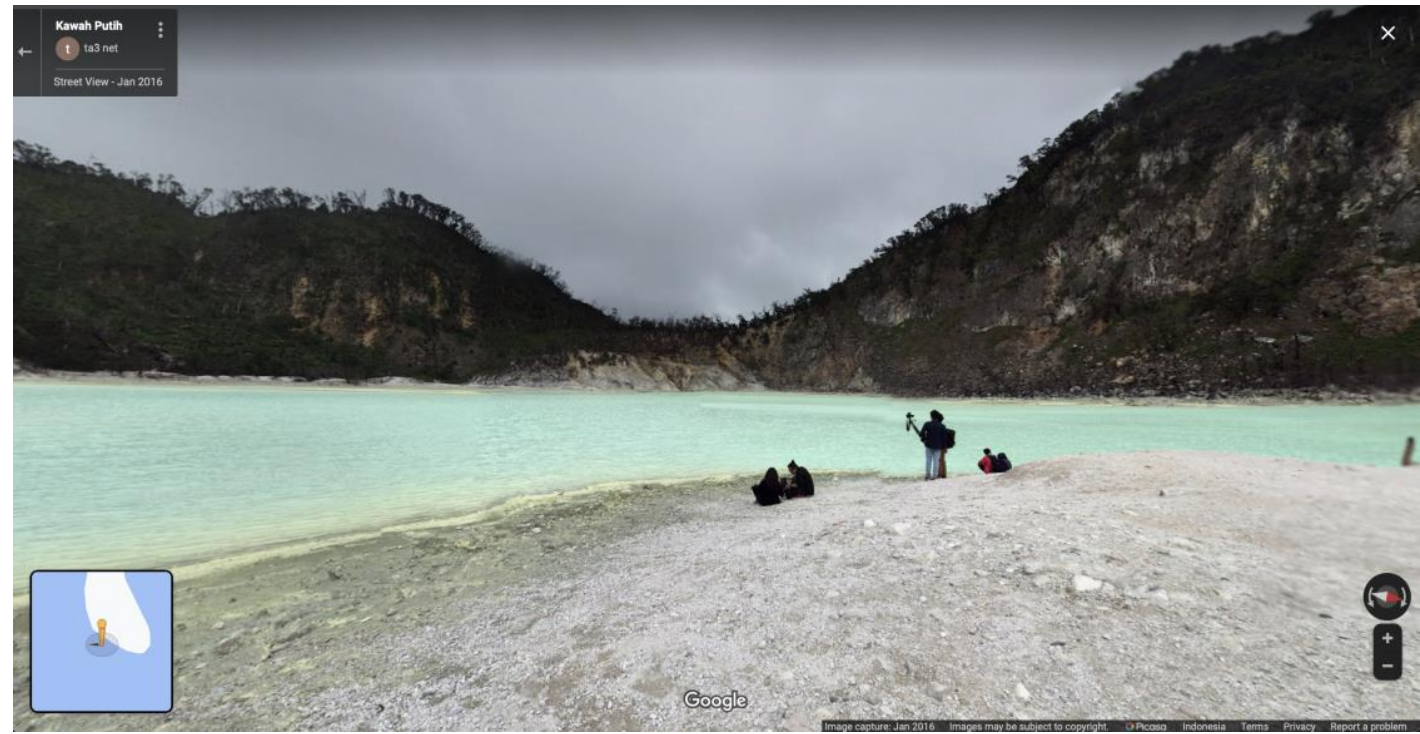

Sumber: Google Street View, 2016

Gambar 8. Pemandangan ke Arah Barat Kawah Sebelum Dibangun Dek (2019)

Riset ini menggunakan model simulasi LCM untuk mengidentifikasi perubahan tutupan lahan dan Sistem Informasi Geografis (SIG) untuk memetakan kondisi layanan ekosistem budaya di kawasan studi berdasarkan indikator-indikator. Penelitian serupa, seperti studi dari Thiele et al. (2020) pada lanskap sungai di Jerman, juga menggunakan indikator dalam pemetaan layanan ekosistem budaya. Proses identifikasi transformasi lanskap menggunakan model pada studi di area Kawah Putih dapat secara cepat 


\section{Transformasi Lanskap dan Layanan Ekosistem Budaya di Area Peri-Urban ...}

memperlihatkan lokasi transformasi dan kedekatannya dengan objek wisata yang dikaji. Hal ini dapat melengkapi studi sebelumnya terkait dengan perubahan kualitas layanan ekosistem budaya pada rentang waktu tertentu.

\section{Pengaruh Wisata dan Perkembangan Permukiman Terhadap Kondisi Layanan Ekosistem Budaya}

Kawah Putih telah berkembang menjadi area wisata alam dengan pembangunan fasilitas penunjang di sekitar kawasan. Fasilitas yang dibangun di antaranya dek kayu yang menjorok ke tengah kawah (Gambar 9) dan Skywalk Cantigi. Penambahan fasilitas ini dapat dilihat sebagai bagian dari proses perubahan lingkungan alami kawasan Kawah Putih. Gerhard et al. (2005) menyatakan bahwa penambahan infrastruktur baru untuk wisata secara ekstrim dapat berakibat pada hilangnya habitat dan banyaknya pembuangan sampah dan penggunaan sumber air, yang pada akhirnya mengubah kondisi ekosistem alami. Berubahnya kondisi lingkungan alami kemudian dapat menurunkan layanan ekosistem budaya dari kawasan wisata.

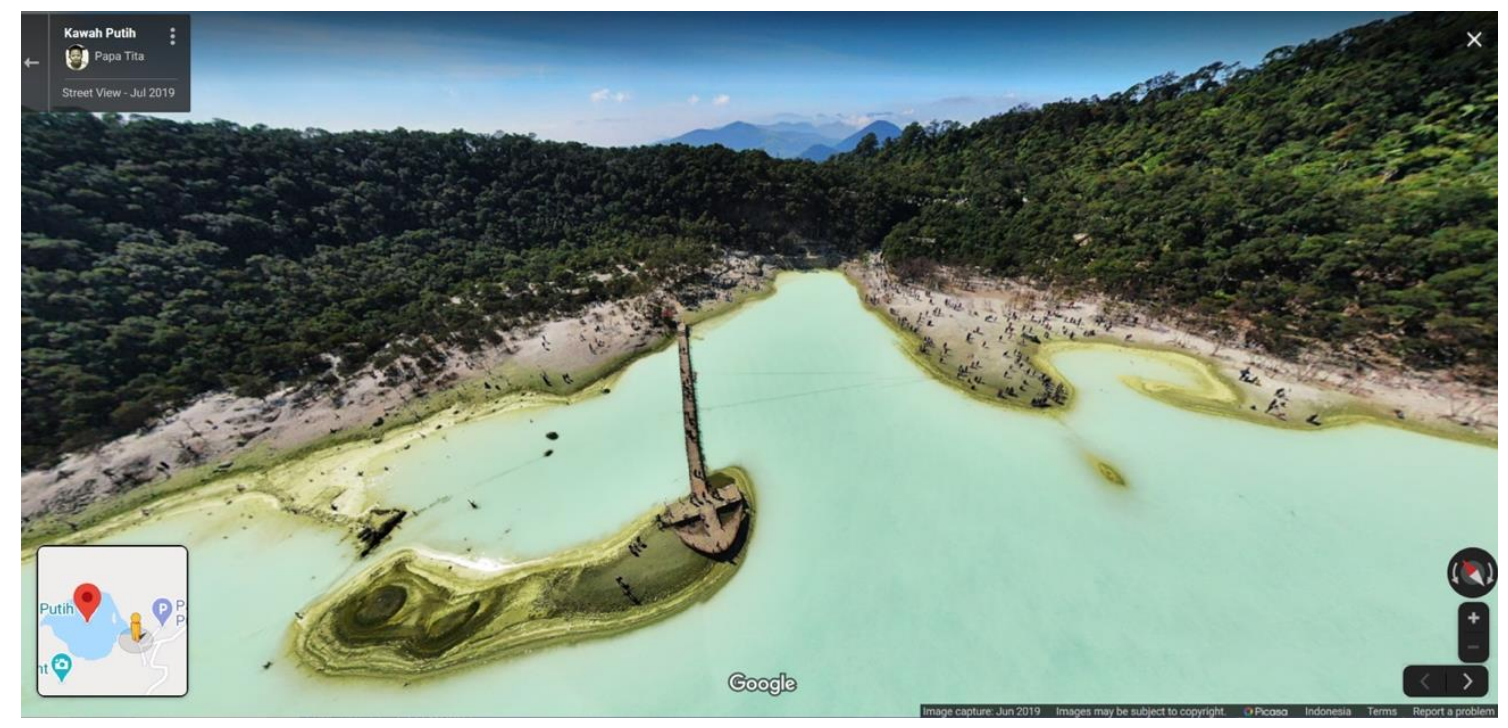

Sumber: Google Street View, 2019

\section{Gambar 9. Dek Kayu untuk Pengunjung}

Perkembangan area terbangun dapat terdeteksi dari gambar Landsat tahun 2019 di bagian timur Kawah Putih, yaitu area parkir (Gambar 4). Selain itu, permukiman baru terdapat di sebelah barat laut dari kawasan wisata tepatnya di sepanjang Jalan Raya Ciwidey - Patengan. Keberadaan objek wisata Kawah Putih berpengaruh terhadap perkembangan warung-warung yang dikelola oleh masyarakat sekitar. Kecenderungan perkembangan fasilitas pendukung yang mendekati objek wisata ini juga terlihat pada studi kasus lain, seperti di area wisata sejarah Bukittinggi (Arianti, 2014).

Jumlah kunjungan kawasan wisata Kawah Putih memiliki kecenderungan naik dari Januari 2016 sampai dengan Oktober 2019 ( $\mathrm{y}=18.336 \mathrm{x}$ - 755565) (Gambar 10), walaupun terdapat perubahan kondisi alami lanskapnya, dari hutan alami menjadi area terbuka (19892019). Gambar 8 menunjukkan batuan kapur sebagai area terbuka yang dimaksud berlatarkan hutan. Hasil dari analisis ini mengindikasikan bahwa penurunan kualitas lanskap di kawasan Kawah Putih (Gambar 6) tidak memberikan pengaruh terhadap kunjungan wisatawan (2016-2019). Namun demikian, hasil analisis tersebut didapatkan dari 
pemetaan tiga indikator dari kondisi layanan ekosistem budaya pada kawasan studi. Sehingga perubahan jenis dan penambahan jumlah indikator dapat memengaruhi hasil dari analisis.

Layanan ekosistem bergantung pada persepsi dan ekspektasi dari pengguna dan pemangku kepentingan (Daniel et al., 2012). Studi yang dilakukan Gatri (2018) mengenai produk wisata di Kawah Putih melalui kuesioner menunjukkan bahwa atraksi, amenitas dan aksesibilitas yang ada dalam area studi secara umum berkontribusi terhadap kepuasan bagi pengunjung. Walaupun terdapat perubahan tutupan lahan pada bagian barat dan selatan kawah yang teridentifikasi dari gambar satelit (1989-2019) (Gambar 4), keberadaan hutan mati di sekitar kawah masih dianggap menjadi area berfoto yang menarik bagi $88 \%$ dari 100 responden pada studi yang dilakukan oleh Gatri (2018). Hal ini menunjukkan bahwa penurunan layanan ekosistem budaya (rekreasi) kawasan Kawah Putih yang diidentifikasi melalui simulasi LCM dan SIG (Gambar 6 dan Gambar 7) tidak berpengaruh terhadap kepuasan pengunjung, yang lebih lanjut dapat terkait dengan fluktuasi jumlah kunjungan (Gambar 10).

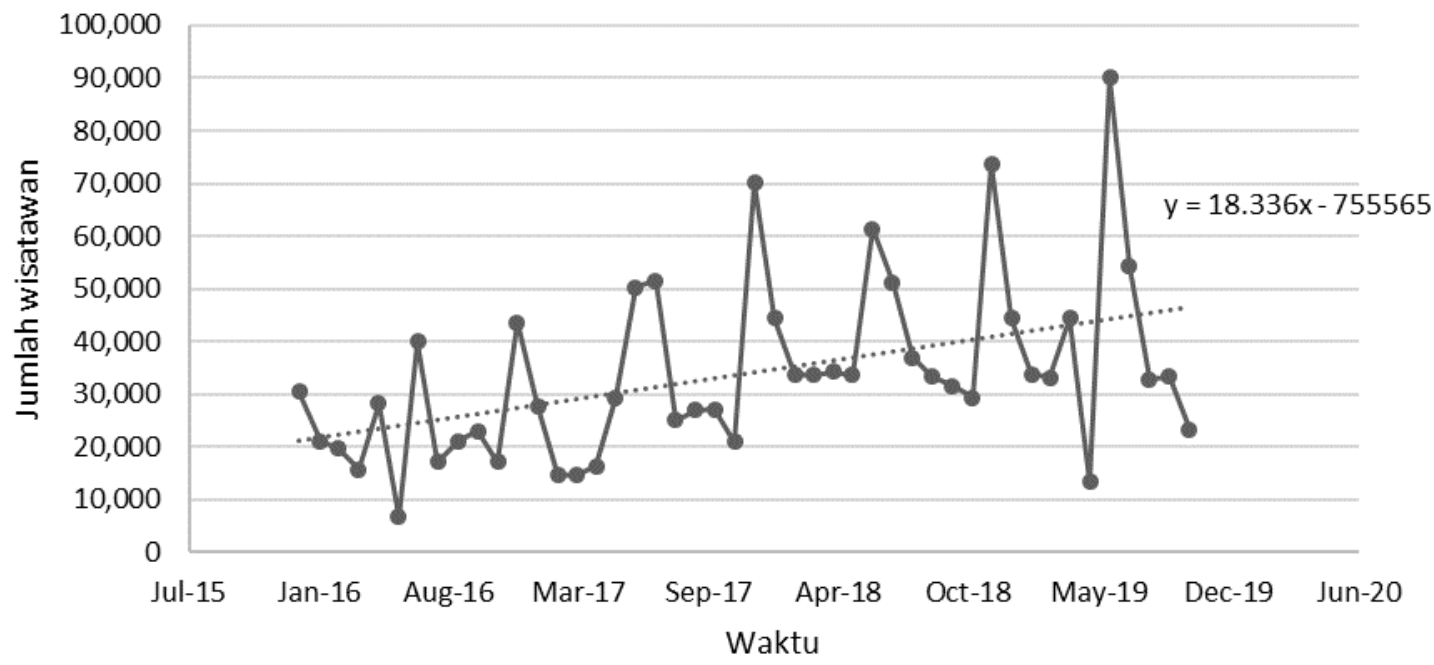

Sumber: diolah dari PT Perhutani Unit III Jawa Barat, 2019

Gambar 10. Grafik Perkembangan Total Jumlah Wisatawan Nusantara dan Asing ke Kawah Putih (Januari 2016- Oktober 2019)

Kawasan peri-urban mengalami transformasi tutupan lahan secara dinamis yang dipengaruhi oleh pertumbuhan kota di dekatnya (Spyra et al., 2020; Woltjer, 2014). Kondisi tersebut dapat terlihat pada Kecamatan Rancabali di Bandung Selatan, berdasarkan hasil analisis menggunakan simulasi LCM. Komposisi area terbangun meningkat dari $6.09 \%$ menjadi $10.79 \%$ dalam waktu 30 tahun di wilayah studi. Hubungan timbal balik (trade-off) antara cultural services dan provisioning services seperti yang dijelaskan oleh Spyra et al. (2020) dapat terlihat pada kawasan tersebut. Terdapat pertumbuhan lahan terbangun menjadi permukiman baru dan intensifikasi kegiatan pertanian di sekitar Kawah Putih. Hal ini dapat mereduksi layanan ekosistem dari lanskap alami, yaitu berupa nilai estetis dan penggunaan lanskap untuk kegiatan rekreasi. Argumentasi dari riset ini yaitu lokasi studi di peri-urban dapat menjadi salah satu faktor pendorong untuk percepatan perubahan tutupan lahan, dibandingkan dengan lokasi yang dikaji terletak pada area lain (de la Barrera et al., 2018), seperti di perdesaan. 


\section{Transformasi Lanskap dan Layanan Ekosistem Budaya di Area Peri-Urban ...}

Menurut Woltjer (2014), perubahan sistem perekonomian masyarakat menjadi bagian dari industri pariwisata merupakan elemen transformasi kawasan peri-urban. Fenomena ini dapat terlihat dari pemberdayaan masyarakat mitra usaha Wana Wisata Kawah Putih, beberapa di antaranya sebagai pengemudi ontang-anting, pedagang di kios, dan pegawai (Soepomo et al., 2018). Terdapat kebutuhan rekreasi masyarakat perkotaan yang mendatangi kawasan peri-urban karena minimnya area terbuka untuk berekreasi di dalam kota (Hedblom et al., 2017). Kondisi ini dapat berpengaruh pada kecenderungan tingginya kunjungan wisatawan dari kota menuju area peri-urban, termasuk di kawasan Kawah Putih yang sudah terdapat akses kendaraan yang baik menuju area wisata.

\section{Kesimpulan}

Penelitian ini dilakukan untuk mengidentifikasi transformasi lanskap (1989-2019) di kawasan Kawah Putih yang terletak di peri-urban dengan mengintegrasikan model dalam proses analisis. Perubahan kondisi layanan ekosistem budaya (rekreasi) di area studi serta pengaruh kegiatan wisata dan perkembangan permukiman terhadap kondisi layanan kemudian dianalisis. Hasil kajian memperlihatkan adanya penurunan layanan kondisi layanan melalui transformasi lanskap terutama pada bagian barat dan selatan kawasan. Area yang berbatasan langsung dengan kawah di bagian barat daya juga mengalami transformasi dari tutupan hutan menjadi kapur. Walaupun demikian, perubahan kualitas estetis lanskap ini tidak memberikan dampak signifikan terhadap kunjungan wisatawan untuk mengunjungi objek wisata Kawah Putih. Persepsi pengunjung terhadap visual lanskap di area studi merupakan faktor yang berpengaruh terhadap hasil tersebut. Adanya transformasi tutupan lahan secara cepat dipengaruhi oleh pertumbuhan kota terdekat, di mana industri pariwisata merupakan bagian dari elemen transformasi.

Kontribusi dari penelitian ini yaitu mengisi keterbatasan studi terkait layanan ekosistem budaya di kawasan peri-urban dengan menggunakan model. Selain itu, studi ini memperlihatkan kerangka analisis untuk mengkaji transformasi lanskap dan kaitannya dengan perubahan kondisi layanan ekosistem budaya (rekreasi), yang dapat diaplikasikan pada kawasan wisata lainnya. Limitasi dari studi mencakup penggunaan data satelit dengan resolusi spasial medium (30 meter) untuk memetakan tutupan lahan di area studi. Penelitian lanjutan dapat dilakukan dengan memanfaatkan data satelit dengan resolusi spasial yang lebih tinggi. Selain itu, nilai reflektansi piksel yang telah berubah karena kondisi atmosfer dan efek topografi lahan selanjutnya dapat dikoreksi, sehingga menghasilkan peta tutupan lahan yang lebih akurat untuk mencapai hasil analisis yang lebih baik.

\section{Ucapan Terima Kasih}

Penelitian ini merupakan bagian dari riset berjudul "Tipologi Permukiman dan Hunian di Peri-urban: Transformasi akibat Pariwisata". Penulis berterimakasih kepada Kementrian Riset, Teknologi dan Pendidikan Tinggi atas dana riset yang sudah dikelola dalam Sistem Informasi Penelitian dan Pengabdian Kepada Masyarakat (simlitabmas) untuk penelitian ini.

\section{Daftar Pustaka}

Arianti, D. (2014). Pengaruh sektor pariwisata terhadap perekonomian dan keruangan Kota Bukittinggi (pendekatan analisis input output). Jurnal Wilayah dan Lingkungan, 2(4), 183-196. doi:10.14710/pwk.v12i4.13502. 
Badan Informasi Geospasial (BIG)

(2018).

from https://tanahair.indonesia.go.id/demnas/\#/.

Champbell, J. B., \& Wynne, R. H. (2011). Introduction to remote sensing (5th ed.). New York: The Guilford Press.

Daniel, T. C., Muhar, A., Arnberger, A., Aznar, O., Boyd, J. W., Chan, K. M. A., ... Von Der Dunk, A. (2012). Contributions of cultural services to the ecosystem services agenda. Proceedings of the National Academy of Sciences of the United States of America, 109(23), 8812-8819. doi:10.1073/pnas.1114773109.

de la Barrera, F., Henríquez, C., Coulombié, F., Dobbs, C., \& Salazar, A. (2018). Periurbanization and conservation pressures over remnants of native vegetation: impact on ecosystem services for a LatinAmerican capital city. Change and Adaptation in Socio-Ecological Systems, 4(1), 21-32. doi:10.1515/cass-2018-0003.

Douglas, I. (2012). Peri-urban ecosystems and societies: Transitional zones and contrasting values. In D. McGregor \& D. Simon (Eds.), The peri-urban interface: Approaches to sustainable natural and human resource use (pp. 18-29). London: Rouledge. doi:10.4324/9781849775878.

Eastman, J. R. (2006). Guide to GIS and image processing. Worcester: Clark University.

Gatri, G. S. (2018). Pengaruh produk wisata terhadap kepuasan wisatawan: Studi pada wisatawan Wana Wisata Kawah Putih Bandung. UIN Sunan Gunung Djati Bandung.

Gerhard, P. H., Lasco, R., Bohensky, E., Domingos, T., Guhl, A., Lundberg, J., \& Zurek, M. (2005). Chapter 7: Drivers of ecosystem change. In The Millenium Ecosystems Assessment Series (MEA). Ecosystems and Human Well-being: Scenarios. Volume 2.

Google Street View. (2016). Google Street View pada kawasan Kawah Putih. Diakses 5 Juli 2020.

Google Street View. (2019). Google Street View pada kawasan Kawah Putih. Diakses 5 Juli 2020.

Haines-Young, R., \& Potschin, M. (2018). CICES V5. 1. guidance on the application of the revised structure. In Fabis Consulting. Nottingham.

Hedblom, M., Andersson, E., \& Borgström, S. (2017). Flexible land-use and undefined governance: From threats to potentials in peri-urban landscape planning. Land Use Policy, 63, 523-527. doi:10.1016/j.landusepol.2017.02.022.

Helmer, E. H., Ruzycki, T. S., Benner, J., Voggesser, S. M., Scobie, B. P., Park, C., .. Ramnarine, S. (2012). Detailed maps of tropical forest types are within reach: Forest tree communities for Trinidad and Tobago mapped with multiseason Landsat and multiseason fine-resolution imagery. Forest Ecology and Management, 279, 147-166. doi:10.1016/j.foreco.2012.05.016.

Kangas, A., Korhonen, K. T., Packalen, T., \& Vauhkonen, J. (2018). Sources and types of uncertainties in the information on forest-related ecosystem services. Forest Ecology and Management, 427, 7-16. doi:10.1016/j.foreco.2018.05.056.

Kosanic, A., \& Petzold, J. (2020). A systematic review of cultural ecosystem services and human wellbeing. Ecosystem Services, 45. doi:10.1016/j.ecoser.2020.101168.

Le, D., Scott, N., Becken, S., \& Connolly, R. M. (2019). Tourists' aesthetic assessment of environmental changes, linking conservation planning to sustainable tourism development. Journal of Sustainable Tourism, 27(10), 1477-1494. doi:10.1080/09669582.2019.1632869.

Linke, J., McDermid, G. J., Pape, A. D., McLane, A. J., Laskin, D. N., Hall-Beyer, M., \& Franklin, S. E. (2009). The influence of patch-delineation mismatches on multi-temporal landscape pattern analysis. Landscape Ecology, 24(2), 157-170. doi:10.1007/s10980-008-9290-z.

Mat-Som, A. P., \& Bader-Badarneh, M. (2011). Tourist satisfaction and repeat visitation; toward a new comprehensive model. World Academy of Science, Engineering and Technology, 50, 1106-1113. doi:10.5281/zenodo.1076526.

Millennium Ecosystem Assessment (MEA). (2005). Ecosystems and human well being: synthesis. Washington: Island Press.

Mngumi, L. E. (2019). Socio-ecological resilience to climate change effects in peri-urban areas: insights from the Pugu and Kazimzumbwi forest reserves of Dar es Salaam, Tanzania. GeoJournal, 86(1), 339-355. doi:10.1007/s10708-019-10071-9. 


\section{Transformasi Lanskap dan Layanan Ekosistem Budaya di Area Peri-Urban ...}

Pratiwi, W. D., Nagari, B. K., \& Jamalianuri, J. (2019). Sustainable settlement development: Land use change in Lakeside Tourism of Bandung. KnE Social Sciences, 883-897. doi:10.18502/kss.v3i21.5019.

PT Perhutani Unit III Jawa Barat. (2019). Laporan Harian Kawah Putih PT Perhutani Unit III Jawa Barat.

Putt, A. E., MacIsaac, E. A., Herunter, H. E., Cooper, A. B., \& Selbie, D. T. (2019). Eutrophication forcings on a peri-urban lake ecosystem: Context for integrated watershed to airshed management. PLoS ONE, 14(7), 1-21. doi:10.1371/journal.pone.0219241.

Slámová, M., Jancura, P., \& Modranský, J. (2018). The quality assessment of forests in the cadastral district of zvolen (Slovakia). Acta Universitatis Agriculturae et Silviculturae Mendelianae Brunensis, 66(1), 183-194. doi:10.11118/actaun201866010183.

Soepomo, S. R. F., Rahmafitria, F., \& Daluarti, M. H. C. (2018). Pengembangan program pelibatan masyarakat di Wana Wisata Kawah Putih. Journal of Indonesian Tourism, Hospitality and Recreation, 1(1), 80-94.

Spyra, M., La Rosa, D., Zasada, I., Sylla, M., \& Shkaruba, A. (2020). Governance of ecosystem services trade-offs in peri-urban landscapes. Land Use Policy, 95(October 2019), 104617. doi:10.1016/j.landusepol.2020.104617.

The Economics of Ecosystems and Biodiversity (TEEB). (2010). The economics of ecosystems and biodiversity ecological and economic foundations. In P. Kumar (Ed.), Management of Environmental Quality: An International Journal. London and Washington: Earthscan. doi:10.1108/meq.2011.08322bae.003.

Thiele, J., Albert, C., Hermes, J., \& von Haaren, C. (2020). Assessing and quantifying offered cultural ecosystem services of German river landscapes. Ecosystem Services, 42(February), 101080. doi:10.1016/j.ecoser.2020.101080.

Tieskens, K. F., Van Zanten, B. T., Schulp, C. J. E., \& Verburg, P. H. (2018). Aesthetic appreciation of the cultural landscape through social media: An analysis of revealed preference in the Dutch river landscape. Landscape and Urban Planning, 177(June 2017), 128-137. doi:10.1016/j.landurbplan.2018.05.002.

Toure, S. I., Stow, D. A., Shih, H., Weeks, J., \& Lopez-Carr, D. (2018). Land cover and land use change analysis using multi-spatial resolution data and object-based image analysis. Remote Sensing of Environment, 210, 259-268. doi:10.1016/j.rse.2018.03.023.

United States Geological Survey. (1989). LANDSAT 4-5 TM. Scene ID: LT05_L2SP_122065_19890706_20200916_02_T1. (6 Juli 1989). Retrieved from USGS Explorer http://earthexplorer.usgs.gov.

United States Geological Survey. (2019). LANDSAT 8 OLI/TIRS. Scene ID: LC08_L2SP_122065_20190911_20200826_02_T1. (11 September 2019). Retrieved from USGS Explorer http://earthexplorer.usgs.gov.

Urban, D. L., \& Wallin, D. (2017). Introduction to Markov models. In S. E. Gergel \& M. G. Turner (Eds.), Learning landscape ecology: A practical guide to concepts and techniques (Second). Springer-Verlag New York.

Woltjer, J. (2014). A global review on peri-urban development and planning. Jurnal Perencanaan Wilayah dan Kota, 25(1), 1-16. doi:10.5614/jpwk.2014.25.1.1. 